\title{
The Black Atlantic as reversal: A reappraisal of African and black theology
}

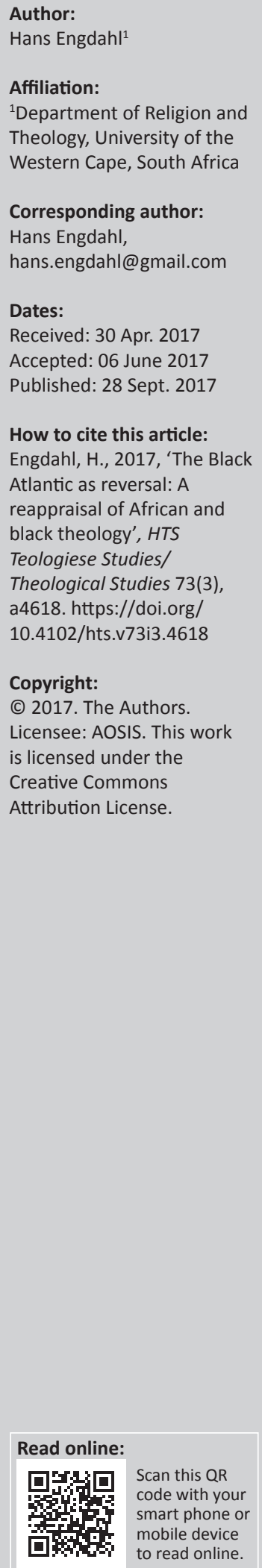

\section{Author:}

\section{Affiliation}

${ }^{1}$ Department of Religion and Theology, University of the

\section{Corresponding author:}

Hans Engdahl,

\section{Dates:}

Received: 30 Apr. 2017

Accepted: 06 June 2017

How to cite this article: Engdahl, H., 2017, 'The Black Atlantic as reversal: A reappraisal of African an black theology', HTS Theological Studies 73(3), a4618. https://doi.org/

\section{Copyright:}

(c) 2017. The Authors. is licensed under the Creative Commons Attribution License.
In this article, I will try to do three things. Firstly, pay attention to the notion of Black Atlantic as coined by Paul Gilroy, which in effect could signify a reversal of colonialism and slavery. Secondly, revisit the 1970s and the debate about the relevance of Black theology vis-à-vis African theology, using John Mbiti's article 'An African Views American Black Theology' as entry point. Here, I will discuss contributions also made by Desmond Tutu and James Cone. Thirdly, starting with the premise that both theologies are relevant and soul mates today, which would (probably) be confirmed by all the above mentioned at this point in time, an assessment of current voices will be made, that is, Tinyiko Maluleke and Vuyani Vellem on black and African ecclesiologies from a South African perspective, and Lawrence Burnley on the fate of the Black Church in the United States.

\section{Black Atlantic as chronotope}

Paul Gilroy has opted for Black Atlantic ${ }^{1}$ as a concept that can keep away from definitions that are too confined and too circumscribed. Being black or African, just the very talk in such terms, lends one easily to start accepting identities that are equal to or are similar to ethnic or national(istic) concerns. Gilroy's mission is different.

Living in Great Britain or in the United States bears out similar kinds of limitations, but also some openings (Gilroy [1993] 2003):

My search for resources with which to comprehend the doubleness and cultural intermixture that distinguish the experience of black Britons in contemporary Europe required me to seek inspiration from other sources and, in effect, to make an intellectual journey across the Atlantic. In black America's histories of cultural and political debate and organisation I found another, second perspective with which to orient my own position. (p. 4$)^{2}$

Having moved westward over the waters to Yale University, he knew very well that there was much more to say than just something on ethnic or national lines. From within the black community, there were other dimensions: There were thinkers (Gilroy [1993] 2003):

who were prepared to renounce the easy claims of African-American exceptionalism in favour of a global, coalitional politics in which anti-imperialism and anti-racism might be seen to interact if not to fuse. (p. 4)

Settling for talking about Black Atlantic, Gilroy has several things in mind. There is the sea and its borders like the continents of Africa, the Americas and Europe. There is the continuous movement west and east, north and south. There are ships and there are people of various categories on these ships. Things here are never standing still. There is perpetual motion. Not to be forgotten, this fluid, ever moving reality, also has a long and very deep history. Gilroy ([1993] 2003) concludes:

I have settled on the image of ships in motion across the spaces between Europe, America, Africa, and the Caribbean as a central organising symbol for this enterprise and as my starting point. The image of the ship - a living, micro-cultural, micro-political system in motion - is especially important for historical and theoretical reasons ... Ships immediately focus attention on the middle passage, on the various projects for redemptive return to an African homeland, on the circulation of ideas and activists as well as the movement of key cultural and political artefacts: tracts, books, gramophone records, and choirs. (p. 4)

One can easily see that the very nature of an ocean would work against any definitive understanding of social reality in terms of, for example, nationalisms or ethnicities. But change 1.In a postgraduate course on 'African Theology, Black Theology and Gender' during the second semester of 2016 at University of the Western Cape, we (Profs. Karin Sporre, Lawrence Burnley and myself) used Black Atlantic as a common denominator or chronotope.

2.Gilroy ([1993] 2003), who is British (European) and black begins his book with the following words: 'Striving to be both European and black requires some specific forms of double consciousness. By saying this I do not mean to suggest that taking one either or both of these unfinished identities necessarily exhausts the subjective resources of any particular individual' (p. 1). 
does not come easy. Gilroy mentions two famous Britons from the 19th century, the master of watercolours J.M.W. Turner and eminent art critic John Ruskin. The latter was for many years the owner of Turner's famous 'picture of a slave ship'. Ruskin developed, along with his pursuits in architectonic and arts criticism, a social concern relating to the New Left, albeit on conservative grounds. Gilroy uses Turner's slave ship as a chronotope ${ }^{3}$ that cuts through and opens up well-established rigidities. The picture portrays how dead and dying slaves are thrown overboard in a severe storm. Eventually, Ruskin put up the painting for sale as 'it is said that he had begun to find it too painful to live with' (Gilroy [1993] 2003:14). The painting ended up in Boston.

\section{Gilroy ([1993] 2003) draws conclusions:}

Its exile in Boston is yet another pointer towards the shape of the Atlantic as a system of cultural exchanges. It is more important, though, to draw attention to Ruskin's inability to discuss the picture except in terms of what it revealed about the aesthetics of painting water. (p. 14)

It seemed as impossibility for a Briton of this time to register that slavery was an economic system orchestrated by the West, not least by the British, and to Gilroy, the relationship between modernity and slavery is an unfinished business. Britain, in some form of nationalism, is an entity in itself, inventing and re-inventing itself:

$[T]$ he aesthetic and cultural tradition in which Turner and Ruskin stand compounded ... reproduced its nationalism and its ethnocentrism by denying imaginary, invented Englishness any external referents whatsoever. England ceaselessly gives birth to itself, seemingly from Britannia's head. (Gilroy [1993] 2003:14)

Even though Gilroy shuns essentialist ways of understanding peoples and cultures, it goes without saying that in the West at least the very notion of a Black Atlantic creates a barrier. But this is exactly the point. Without such a notion, the African diaspora emerging into America and now Europe is made invisible. The first step is to see this diaspora as a western reality as well. Again, Turner's painting is such a powerful image that speaks to England's ethical and political degeneration but also about means of communication (Gilroy [1993] 2003):

Turner's extraordinary painting of the slave ship remains a useful image not only for its self-conscious moral power and the striking way that it aims directly for the sublime in its invocation of racial terror, commerce, and England's ethico-political degeneration. It should be emphasised that ships were the living means by which the points within that Atlantic world were joined. (p. 16)

Then, if you want to lay bare the intricate relationships between industrialisation, modernisation on the one hand and slavery and oppression on the other, it may indeed be quite necessary to talk explicitly about the Black Atlantic (Gilroy [1993] 2003:17): 'Ships also refer us back to the middle

3.A. unit of analysis for studying texts according to the ratio and nature of the tempora. .'. Chronatope is of course derived from the Greek words Chronos, time and Chronotope is of course derived from the Greek words chronos, time and topos, place; therefore one could say it is integrating history and geography into one reality (my comment). passage, to the half-remembered micro-politics of the slave trade and its relationship to both industrialisation and modernisation'. The task then is to (Gilroy [1993] 2003:17) 'rethink modernity via the history of the Black Atlantic and the African diaspora into the western hemisphere'.

\section{Revisiting the 1970s}

There was a rather fierce debate at this time regarding the role of African theology and black theology. The actual exchange of views took place in the 1970s and what was said was published at the end of that decade.

Mbiti wrote an article on black theology from the perspective of African theology, his perspective, which sparked off immediate reactions. I will here confine myself to this article and the response from Tutu and Cone.

Firstly, one must say, with emphasis, that Mbiti expresses his admiration and gives full credit to the cause of black theology, but, interestingly, draws no conclusions whatsoever regarding the extent to which this theology could have an impact on African theology.

However, his appreciation is solid but tinged with a sense of sadness and pain (Mbiti 1979):

Black Theology is a painful phenomenon in the history of the Church ... because it has emerged in an America that, since the arrival of the Pilgrims in the seventeenth century, has claimed to be a Christian country. Black Theology is a judgment on American Christianity in particular and Christianity in general. Ideally there would be no reason for Black Theology. It was forced into existence by the particularities of American history. (p. 477)

The cause is rooted in the history of slavery (Mbiti 1979):

The roots of Black Theology must in fact be traced to a much earlier period of American history, the arrival of the first African slaves in the seventeenth century. The sub-sequent history of Americans of African origin - of exploitation, segregation and general injustice - is the raw material of what we now call Black Theology ... (It) was born from pain and communicates pain and sorrow to those who study it. It is a cry of protest against conditions that have persisted for nearly four hundred years ... (p. 477f.)

Strong sympathies, yes, but he also does not hide the fact that he sees himself as a mere spectator. As someone brought up in rural Kenya, he continues (Mbiti 1979:480f.): 'It is impossible to offer anything but provisional comments, for I am still digesting Black Theology and admiring it as a specifically American phenomenon ...'

Great admiration, but it is something that he is not involved in (Mbiti 1979:481). 'Standing as I do at a distance, I am impressed with this sudden eruption of theological liveliness in America'.

Although expressing his honest and great admiration for this new theology, he also adds one sentence, which clearly would irritate and possibly anger black theologians for a 
long time to come (Mbiti 1979:481):4 'I understand the reasons for their bitterness, their anger, their hatred, all of which comes through in their Black Theology'.

It was an unfortunate comment which you can easily discern from Cone as well as Tutu. Cone (1979) remarks:

I was especially disturbed by Mbiti's assertion that 'Black Theology ... is full of sorrow, bitterness, anger and hatred'. I know of no Black theologian who would accept this description of Black Theology. (p. 500)

Tutu is also apprehensive. As far as he is concerned (Tutu 1979:485f.), neither Paul nor the author of the Book of Revelation held back their anger or even hatred, so why point out this kind of theology as so full of bitterness and hatred?

But, according to Mbiti, there are other more substantial problems that need to be discussed. He especially finds the singular emphasis on blackness and liberation problematic. This fixation on colour is a typical American phenomenon. Black theology eventually gets itself locked up in a concept that does not carry with it any biblical reference whatsoever (Mbiti 1979):

It wants to see 'blackness' in everything ... It is a color terminology arising out of the color consciousness of American society... It is necessary to remind oneself that racial color is not a theological concept in the Scriptures. (p. 478)

Then, the one-sided emphasis on liberation. Mbiti contends that the 'excessive preoccupation with liberation may well be the chief limitation of Black Theology' (Mbiti 1979:479). Yet, some ambiguity is showing as he also seems to appreciate the dire plight of being black: 'Without the American history of slavery, racism and domination by whites ... there could be no Black Theology' (Mbiti 1979:479). But, there is no reference here to the plight of being African in colonised Africa whatsoever.

Again, some ambiguity as he now approves of liberation as political, ecclesiastical, educational and cultural (Mbiti 1979):

Black Theology simply provides a theological dimension to the concept of liberation, a dimension for which there is a great deal of biblical support. Black Theology speaks of liberation in all spheres of the black experience in America - social, economic, political, ecclesiastical, educational and cultural. (p. 479)

He correctly affirms that Cone's first two books emphasise liberation as the mode of operation for black theology. Liberation is the content of theology as Jesus' work essentially is liberative. Even black rebellion could (should) be seen as God's liberating work. ${ }^{5}$

Theological praxis needs to be articulated. Mbiti (1979:481) utters the following words, as it were, merely in passing: 'But

4.One should also remember that Mbiti at this time, already, was a key African figure in the ecumenical world, currently holding the position as Director of the Ecumenical Institute in Bossey, Geneva. He had also already published extensively on African theology.

5.See James Cone, Black Theology and Black Power, and James Cone, A Black Theology of Liberation. In his first book (Cone 1969:38), he says that ' $[b]$ lack rebellion is a manifestation of God himself actively involved in the present-day affairs of men for manifestation of God himself actively involved in the present-day affairs of men for
the purpose of liberating people'. See also the second book (Cone 1972:22-41) the purpose of liberating people'. See also the second book (Cor
where he deals with 'The sources and norms of Black Theology.' even in Southern Africa the people want and need liberation, not a theology of liberation'. Tutu (1979) questions this statement, as if it was questioning the very notion of liberation theology:

I am not quite sure that I understand what Professor Mbiti in the article I have referred to means when he says that people in Southern Africa 'want and need liberation, not a theology of liberation'. Could we not say the same thing about a theology of hope that what people want is hope, not a theology of hope? (p. 489)

This exchange is vitally important. Mbiti's comment opens the door to a discussion about the meaning of theology and its contextuality. A theology involved in praxis will sooner or later end up with a concrete programme aligning itself with a liberative or conservative agenda or something else. Being a substantial, albeit minority, seemingly perpetually, black Americans know this dilemma better than most. One could even sense this when Cone expresses himself (Cone 1979:494f), thus regarding the wider African and Black world scene: 'International economic and political arrangements require a certain kind of African and Black nationalism if we are to liberate ourselves from European and White American domination'. It may be enough to point out that it is far from unproblematic to say that Black Nationalism is a goal, as any nationalism could be deemed problematic. The quote is a good illustration of how vital it is to grapple with just this relationship between liberation theology and liberation, be it in southern Africa or not. ${ }^{6}$

In all honesty, Mbiti adds also a question to liberation theology that is rather critical: when the immediate concerns of liberation are met, what then? He then states (Mbiti 1979):

(It is) not at all clear where Black Theology is supposed to go. Black Theology is deeply 'eschatological', yet its eschatological hopes are not clearly defined. There is no clue as to when one arrives at the paradise of 'liberation'. One gets the feeling that Black Theology has created a semi-mythological urgency for liberation that it must at all costs keep alive. As a result it seems that Black Theology is avoiding other major theological issues not directly related to 'liberation'. (p. 479f.)

However, Mbiti finally wants to say where he comes from. Slightly antagonistic, he says (Mbiti 1979):

African Theology ... grows out of our joy in the experience of the Christian faith, whereas Black Theology emerges from the pains of oppression. African Theology is not so restricted in its concerns, nor does it have any ideology to propagate. (p. 481)

He also makes an attempt to portray the richness of African theology (Mbiti 1979:482): 'African Theology is concerned with many more issues, including all the classical theological themes, plus localized topics, such as religious dialogue between Christianity and African Religion ...'

6.I experienced an example of the need to articulate this relationship once, and it 1990s. I was in Angola with the Swedish ambassado attending a celebration of the Cubans' contribution in the struggle for liberation in Angola. When introduced to the Cuban ambassador to Angola, I expressed my appreciation, adding that I saw the importance in pursuing liberation theology. He looked at me almost in a fiendish way, as if I had said something very stupid. He simply could not see, I think, the point in talking about liberation theology. I never had an opportunity to explain any further. 
Tutu could here be seen as a go-between. As African and black, he has both perspectives. However, the (church) struggle against apartheid in South Africa makes him come out more on the side of black theology.

Tutu will now fill a void that Mbiti has not filled. It is about the theological commitment to African society at large. He is blunt (Tutu 1979):

I fear that African theology has failed ... to speak meaningfully... about the theology of power in the face of the epidemic of coups and military rule, about development, about poverty and disease and other equally urgent present-day issues. I believe this is where the abrasive Black Theology may have a few lessons for African theology. In short, African theology will have to recover its prophetic calling. It can happen only when a radical spiritual decolonization occurs within each exponent of African theology. (p. 490)

At two occasions, Tutu mentions the African ability to keep up with life in its being corporate. Slightly surprising that he does not link up with Mbiti here. For Mbiti, this is one of the unavoidable consequences of being an African. ${ }^{7}$ Tutu (1979) leaves us with this exhortation:

Let us develop our insights about the corporateness of human existence in the face of excessive Western individualism, about the wholeness of the person when others are concerned for Hellenistic dichotomies of soul and body, about the reality of the spiritual when others are made desolate with the poverty of the material. (p. 490f.)

Tutu (1979:485) has one comment not heard from the side of Cone or Mbiti: 'We are compelled to help the white man to correct many of the distortions that have happened to the gospel to the detriment of all' ${ }^{8}$

To conclude, Tutu says, I am for both, thank you. What he ends off with has become a classic in African scholarship. Starting by saying that for him to do black theology in South Africa is to do African theology, he then continues (Tutu 1979):

I myself believe I am an exponent of Black Theology coming as I do from South Africa. I also believe I am an exponent of African theology coming as I do from Africa. I contend that Black Theology is like the inner and smaller circle in a series of concentric circles. (p. 490)

Cone takes Mbiti very seriously treating him with great respect which behoves a leading African scholar. However, in doing so, he at the same time gives another distinctively different version of what should be the relationship between African and black theology.

His point of departure is then quite different from Mbiti, but also from Tutu. He admits without reservation that being black in America, that is, United States, creates an unresolved dilemma, expressed by so many, but probably most 7.Interestingly, Cone does not raise the issue of corporateness.

8.Tutu is here paraphrasing Manas Buthelezi who once said, 'where were you when the white man did this to the gospel?' pertinently expressed by W.E.B. Du Bois: 'It is a peculiar sensation, this double consciousness, this sense of always looking at one's self through the eyes of others ...' (Cone 1979:493; Du Bois [1903] 1961:16f.).

Even though his mind is full of ideas of how African theology should operate, he also has the honesty and humility to say at the opening that coming from a different continent could make him not see things that he should see (Cone 1979:492): 'The effect of this social reality upon my theological perspective could blind me to the uniqueness of the African situation'.

One should bear in mind that Mbiti had just taken black theology to task, Cone style, sharply so, and yet Cone's reaction is very measured. He takes note of the fact that he himself is coming from a different background (Cone 1979):

$[M] y$ disagreement with Mbiti and other African theologians who separate radically African Theology and Black Theology does not mean that I believe that Black Americans should play a major role in the formulation of the meaning of African Theology. My contention (however) is that Black and African theologies are not as different as has been suggested ... (p. 494)

To be sure, there is a common origin (Cone 1979):

The history of American Blacks cannot be completely separated from the history of Africa. Therefore, whatever may be said about the significant distinctions between Africans and Black people of the American diaspora, there was once a time when these distinctions did not exist. The significance of this point extends beyond a mere academic interest in historical origins. (p. 494)

Cone's black theology is structured as a (theological) struggle against a clearly defined enemy. Mbiti is well aware that there was and that there is an enemy, but in constructing his theology, one could say that he is going out of his way to avoid this very struggle, for whatever reason, but at least one reason being to meet the dire need to articulate what is African theology without immediate reference to either the West or colonialism as such. Cone's entry into the discussion actually takes place via what came to be called EATWOT. ${ }^{9}$ This ecumenical body would play an important role in challenging the superiority and dominance of western theology in general.

This is a forum which would take care of the common interest of both parties: ${ }^{10}$

The oneness that I refer to is made possible by a common historical option available to both Africans and Black Americans in their different social contexts. Each of us can make a choice that establishes our solidarity with the liberation of the Black World from European and American domination. (Cone 1979:495)

This body made it possible to take on the West from the perspective of the whole of Asia, Africa and Latin America:

9.Ecumenical Association of Third World Theologians, a World Council of Churches related body; at this time, in the 1970s, however, it was called the Ecumenical Dialogue of Third World Theologians (Cone 1979:495).

10.Early on black North American, theologians were welcomed into this fellowship. 
This domination is not only revealed in the particularity of American White racism or European colonialism in Africa, but also in Euro-American imperialism in Asia, Latin America, and the Caribbean ... This global perspective requires that we enlarge the oneness of the Black World to include our solidarity with the world's poor. (Cone 1979:495)

There is also an evangelistic zeal that needs to be expressed (Cone 1979):

The possibility of substantive dialogue between African Theology and other Third World theologies is created not only on the basis of our common historical option, but also on the basis of our common faith in Jesus Christ. (p. 495)

Yet, the universal claim of the gospel is not forgotten (Cone 1979:496): 'Therefore, we must ask not only what does the gospel mean for me in Africa or North America, but also for Christians in the whole inhabited world'.

Last year (2016), it was the 50 years anniversary of the publication of Cone's book, Black Theology and Black Power. Cone's impact is hard to overestimate. Consistently, he has, on a firm Protestant theological basis, articulated the call to resist and fight white racism and oppression. Fifty years later, there is still a need to make such a clear call.

Cone stands out as much relevant still today. ${ }^{11}$ He gives a new dimension to African theology, not provided by Mbiti. Yet, there is mutual respect. Both theologies are needed. On basis of black theology, Cone has demonstrated that African theology, as the old school, has a basic role to play. But, he never substantiates what is African theology proper. Admittedly, he gives credit to Mbiti for his scholarship (Cone 1979:500).

\section{Contours of current South African Black ecclesiology}

I will here give examples of how black theologians in South Africa at this time, on the one hand stand in the tradition of black theology of the 1970s, on the other bring this tradition further insisting on an ecclesiological context.

Firstly, it would be of great interest to find out where Tutu stands regarding the church, and after that, I like to look further into what black ecclesiology could look like now in South Africa.

Those who know anything about Tutu as a man of the church would also place him firmly within the Anglican Church. ${ }^{12}$ But, he was literally shaped in a quite different ecumenical milieu of the black church in the poor townships in western Johannesburg. His basic theological insights were made in this township church way before King's College, London. Black people struggled just to make a living, but in this very

11.The one thing that sticks out though as something dated is his reference to Canon Burgess Carr and the legitimate use of violence (Cone 1979:497).

12. He was the first black archbishop of the Church of the Province of Southern Africa (now the Anglican Church of Southern Africa) in 1996. situation of hardship the church was present, in the everyday life, in all sorts of ways. This is vividly illustrated by Tutu's childhood. This is still in many ways typical South African township life. The church is there in all its shapes. One could truly talk about the ecumenical church, which means that many denominations are on offer, and families would often times freely make their choices, individually or collectively. In Tutu's case, it was like this. His father worked as a teacher at a Methodist school, and his grandfather was an African Independent Church minister. As a boy, he frequently joined his uncle, also a priest in this African Independent Church (Allen 2006:34; Maluleke 2015:578).

Even more important must have been the fact that the church was present also when suffering and death made themselves present (Allen 2006:21; Maluleke 2015:578f.):

One of Desmond Tutu's memories of 'the church' - before he was ten ... must have been on occasion of the funeral of his deceased younger brother, Thamsangqua, who died as an infant. Apart from the emotional toll that comes with the loss of a sibling, the pain of watching one's parents in pain, even before one understands death and its devastation fully, the funeral was memorable for the young Desmond because (his father) conducted it himself, as the local minister was absent ... On the plus side, the church of Tutu's childhood was always present, below the surface; it convened as and when needed, with or without a priest in attendance.

Tutu lived in a family environment that was peripatetic and he did not seem to mind. They moved house but they also moved church (Maluleke 2015:579; Tutu 2015:126):

When my older sister became friendly with the daughter of an African Methodist Episcopal Church (AME) pastor, I became a member of that church: it's a Black church that came from the United States; episcopal - with bishops. Very beautiful singing. Then my sister went to an Anglican (boarding) high school ... and she said she wanted to be confirmed as an Anglican. My parents said yes that was ok, and we all duly followed her into the Anglican Church.

What also made a great impact on Tutu was his encounter later on with fathers belonging to the Community of the Resurrection. Eventually, he became a close friend of Father Trevor Huddleston, of whom he eventually would say that he 'single-handedly made Apartheid a world issue' (Maluleke 2015:577; Sparks \& Tutu 2011:27).

The true story worth telling is the one with President P.W. Botha. The first encounter occurred in 1988 (Maluleke 2015:585), 'when he intended to plead for clemency on behalf of the Sharpeville six'. The second and third encounter occurred almost 10 years later, retired as Botha was from being South Africa's President. In the 1988 meeting, he ignored Tutu totally and treated him like a school boy. In that very meeting, Tutu lashed out at the President telling him that he was a leader of the church in his own right (Maluleke 2015:585f). The fact that he let fly at the country's president surprised many, but one can see this trait all the way through his church ministry. The church must care, take a stand, speak up, must never become complacent. 
The second encounter at his home in Wilderness was a call to Botha to come and testify before the Truth and Reconciliation Commission. He declined. A few weeks later his wife died. Tutu came a third time to Wilderness. In Tutu's own words: 'I came as a loving husband to stand beside another loving husband in grief' (Maluleke 2015:590; Tutu \& Tutu 2014:144).

These are remarkable words. Tutu has been steeped in a meaningful and rich church life, basically in the impoverished, black church in Johannesburg's western townships. Way after his pension, under the auspices of the TRC, he goes out of his way to be a true pastor to South Africa's former president, coming to his home, again. He is this church, a church that has the world and its entire people, high and low, at her heart. And, when going to Botha, again, in a strange way he is doing it as representative of the black church more than anything else (which of course at least in his own understanding is part of the total church).

Secondly, I have chosen to have a closer look at an attempt to appropriate black ecclesiology as motion, as a 'going up', as ukunyuka $a^{13}$ (Vellem 2015:651).

According to Vellem (2015:651), this is a logic follow-up of a black theology that was launched some 50 years ago in the United States. This logic is twofold. Firstly, there is a justifiable cause for upholding the notion of blackness, even today, 50 years later. Secondly, there is a justifiable cause for taking the step from theology to ecclesiology, the latter being a logic outcome of the former.

It is a breakaway from any sort of compromise (Vellem 2015:654). Of settler church, mission church and black church, only the last one will make sense. ${ }^{14}$ Black theologies (black and African) are soul mates, clarified many years ago (Vellem 2015:653). It is about 'a rupture, an epistemological break from Western traditional and orthodox theological concepts and categories'. 'Ukunyuka is imagined from the underside or underbelly of modernity' (Vellem 2015:652). Thanks to the mission conquest among the Xhosa, two groups were formed, the black Christians, giving up their Xhosa culture, the Amagqhoboka, and the Amaqaba, 'defending their cultural dispensation at all costs' (Vellem 2015:655). 'Double consciousness' as W.E.B. Du Bois has it, will have to be resolved somehow (Eze 2011:225; Vellem 2015:656).

\section{Therefore, in the end (Vellem 2015):}

Black ecclesiology does not and cannot be a product of a bifurcated system of knowledge, categories, and concepts. Black ecclesiology is critical, thus criticality of consciousness is a central pivot to grasping the tenets of black ecclesiology and black faith praxis. (p. 656)

Vellem clearly sees the trajectories of uprisings over against the 'oppressive legislation since 1948, when the Nationalist

\section{Ukunyuka, isiXhosa for 'going up' (Vellem 2015:651).}

14.Vellem (2015) also says: Our South African narrative of Christianity, as in othe places in the global South, is a tainted text of colonization and conquest that make it implausible to exculpate the settler and the missionary models (p. 655).
Party came to power in South Africa'. What is clear is that he is here writing from a black theology of liberation perspective (Vellem 2015:652).

A black theology of liberation inevitably leads to a black ecclesiology.

Like Gilroy, Vellem (2015) finds deep problems with the modern project:

Against the Enlightenment paradigm or modernity, a Black Theology of liberation challenges the notion of 'objectivity' and argues that it is hard to find a theology that is devoid of prejudice, prejudgements, or presuppositions. (p. 660)

The 'grammar' is different from that of Western, orthodox theology, especially when it comes to 'the place of a nonperson, a black interlocutor in the theological reflection'. The philosophy of black consciousness became the necessary presupposition: 'In South Africa, Black Consciousness provides what could be understood as the side of "reason" if one thinks about faith and reason together in theological discourse'. African and liberation philosophies complete the picture.

It goes without saying that a body is needed where this theology could be articulated. In other words, the church is needed. But, it is a church that only knows the dire need of uprising and struggle (Vellem 2015):

In its rudimentary phase, the spirituality of liberation found expression outside the conventional walls of the church. This spirituality 'born of tragedy' was marked by the formation of African Initiated Churches and the Ethiopian Movement as a black response to the settler and missionary models of ecclesiology. Within this phase, in which a black spirituality is distinguishable from white spirituality, we find the roots of black faith as socio-political praxis ... The systematic articulation of black ecclesiology identifies the black struggling person as its interlocutor within the tragedy of colonization, conquest, and Christianization and now democratic South Africa and Empire. Everywhere that we find this struggle, we find black ecclesiology. (p. 661)

The ecumenical ideal of a visible Christian unity manifested by the church seems far off (Vellem 2015):

Black faith, from the rudimentary and systematic phases of Black Theology of liberation, ipso facto, black ecclesiology, treats settler and missionary ecclesiologies as racialized constructs. A black self-conscious ecclesiology does this by valorizing black culture and epistemologies for the humanity of black persons. (p. 662)

To the debate whether there is a need for black and liberation theology in South Africa in the post-1994 era, Vellem (2015) has the following to say. The time of uprising is not over:

$[T]$ he question is not about the relevance of Black Theology and thus black ecclesiology post 1994, but what the post-1994 democratic dispensation does to the former. It is the progression of racist logic, neo-colonial and economic exclusion related to modernist constructs that the prism of black ecclesiology would focus on. (p. 662)

15.These churches are, by virtue of their existence as African churches, because long well informed by the world of Mbitian African theology (my comment). 
Far from being the rainbow nation in the sense of a just dispensation, blacks rather find they must start from scratch. Many still find themselves in a 'zone of nonbeing'. ${ }^{16}$ According to Fanon, this zone is the source of renewal (Fanon 1952:xii; Vellem 2015:662): 'There is a zone of nonbeing, an extraordinarily sterile and arid region, an incline stripped bare of every essential from which a genuine new departure can emerge'.

The Tutuesque zeal being 'intensely non-racialist' is challenged (Vellem 2015): ${ }^{17}$

Christianity may be in crisis, but not black ecclesiology. The rupture of black faith from Eurocentric categories of ecclesiology will be possible with the convergence of resistance energy found outside Western ecclesiological constructs to build critical consciousness at profound theological and ecclesiological levels. (p. 663)

One could see that Vellem's argument is understood also within African-American thinking. Lawrence Burnley, for example, writing about the emergence of church schools from the late 19th century onwards, within the Disciples of Christ, finds that striving for unity within that church actually distorted the whole idea of being church, at least from a black perspective.

Burnley (2008:362) confirms the need for black Disciples to create space exclusively for blacks in national settings for the purpose of fostering and sustaining empowerment ...'

Justice and fairness must develop within the Christian community before you can talk about unity. Vellem's case for a black ecclesiology is put in perspective and makes it a reasonable one (Burnley 2008):

Before integration, reconciliation, or Christian unity can occur within the Disciples of Christ movement, black Disciples must create for themselves intentional and structured forums of separation so that they can be empowered to facilitate dismantling the nihilistic reality in our communities and ultimately reconciliation with others. (p. 377)

\section{Black Atlantic as reversal}

Gilroy ([1993] 2003) declared from the beginning that his hope was that:

the contents of this book are unified by a concern to repudiate the dangerous obsessions with 'racial' purity which are circulating inside and outside black politics. It is, after all, essentially an essay about the inescapable hybridity and intermixture of ideas. (p. xi)

Thus, this hybridity or as Taiye Selasi (2014 [2013]:323, 325) insists, this Afropolitan self-assertion ${ }^{18}$ makes Black Atlantic

16.Vellem also plays on the word 'zone', as this word traditionally has connoted the different sections of a black township.

17.At the height of the debate between Black Theology and African Theology, Tutu voted for Black Theology even though he actually argued that the two were soul mates rather than antagonists. And yet, Tutu was also 'intensely non-racialist' (Khabela 1991:70; Maluleke 2015:587).

18.We are Afropolitans: not citizens but Africans of the world ... [T] he way we see our race - whether black or biracial or none of the above - is a question of politics rather than pigment (Selasi 2014:323, 325). its chronotope, and I contend is wholly at home with black consciousness. It is about knowing and understanding the vital role played by African and black people in forming what is today Europe and America (not only the United States). And it is a complete rejection of Britain's 'reinventing itself'. Differently put, the slave ship watercolour painting by Turner, this masterpiece with a message - slaves thrown overboard signifying the horror of the slave trade, the colonialists' invention, because of greed and total disregard for black people - was too much to stomach for John Ruskin, that is, we are faced with the British self-perpetuating world, here representing the West, a racist place with no room for the other.

Gilroy ( [1993] 2003:14) writes: 'denying imaginary, invented Englishness any external referents whatsoever'. The slave ship painting could have been the first sign of a total rejection of slavery and the colonial project as such and could have led to subsequent remorse and restitution. He gives the impression of being held back. Stating the denial of 'any external referents whatsoever' could be seen as severe confinement on his part. But it need not be so. ${ }^{19}$

Reading Mbiti, Tutu and Cone some 40 years later is of great interest. They stand their ground. And in some ways, little has changed. Mbiti is standing a bit aloof from what he saw as black theology. He merely is the spectator. In his comments, he comes close to being apolitical. It is possible to take this kind of position. Black theology as liberation theology still has some hard questions to grapple with. He is incisive and to the point when he asks the question, why liberation theology, why not just liberation?

Tutu is almost expressing anger facing Mbiti's aloofness and yet pays greatest respect to him. From his article, it stands clear that Tutu, at this time, is firmly within the black theology camp.

Cone is a pillar of strength and pays greatest respect to Mbiti. Until today, they have not changed but work and think along two different lines. Cone has 50 years of black theology, and his cause is still highly relevant. But, Mbiti is highly relevant in his way as well. ${ }^{20}$

Liberation theologians also have a political agenda for very good reasons. Mbiti does not.

My guess is that Cone would gladly join Gustavo Gutierrez (1978) who argues that liberation theology does have a political edge for the sake of the oppressed and continues:

The popular liberation movement poses new questions, theological as well as socio-political, and these questions, rooted in liberation practice, are both a starting point and ultimate criteria for liberation theology. (p. 227)

19.There is here an amazing potential for collaborative research and activism with Black Atlantic as chronotope. The global significance of any such undertaking is a given, but the Black Atlantic contains the inevitable truth: Western initiatives will given, but the Black Atlantic contains the inevitable truth
be at a loss unless African contributions carry weight.

20.See my draft chapter presented at University of the Western Cape, 'John Mbiti and African Religion and Philosophy', in April 2015, and my forthcoming book, African Theology - Ancient and Modern. A Study of Origen and John Mbiti. 
In this sense, Mbiti and Cone are worlds apart. African theology and black theology - soul mates? I would venture to say, for the sake of Black Atlantic and for the sake of the continent of Africa, sooner or later they will have to collaborate more closely.

Tutu and Cone express a scathing criticism of Mbiti merely being a spectator. Also, this criticism is valid today. But, what about Mbiti's massive contribution to African theology? Had they read his work on the African concept of God, the African concept of time, the living-dead, corporateness of human existence in Africa, etc.? The text gives the impression that they have not read Mbiti's texts, just his article. This conclusion drawn as they do not really engage with African theology done by Mbiti.

Tutu is still in focus thanks to Maluleke. His portrait is drawn, I contend, with a specific purpose. Dealing with his background, from childhood onwards, he is able to unearth deeper levels of influence. He is thus moving into what is way before what one could call TRC rhetoric and Anglican ecclesiology. These overshadow the real Tutu. Maluleke makes clear that Tutu's church during the formative years was the black township church on the western side of Johannesburg, a church of the evangelical, protestant type. It is not so difficult to see a link from this reality to an engagement with black consciousness and black theology.

Vellem is firmly grounded in black ecclesiology. There is no time for bifurcation. What he says makes sense when discussing the old texts of the 1970s, but also in relation to Gilroy's chronotope Black Atlantic. This notion of Black Atlantic is conducive to black consciousness, understood as devoid of ethnic or nationalistic encroachments.

Black Atlantic could be seen as a reversal. Vellem quotes Fanon about the zone of non-being and gives references to South African township planning. In the bigger picture, Black Atlantic is that zone of non-being, 'from which a genuine new departure can emerge'.

This zone of non-being is also going to be the great reversal, which may take on the following shapes.

Firstly, the Atlantic, the Middle Passage, is the grave of history. It is the grave of death which will meet its resurrection. In Christ, that is the great reversal.

Secondly, it will be discovered that black ecclesiology in South Africa is a paradigm also for blacks in the United States and in Europe, or anywhere. This is also a great reversal. In the same vein, Black Atlantic will eventually mean that African theology and black theology will engage with each other constructively. What is African will no longer be confined to the continent of Africa. What is black will no longer be seen as alien to America or Europe. Things will be held together by the chronotope of black Atlantic.

In the end, and this is my conviction, black ecclesiology will be seen to carry the seed of catholicity ${ }^{21}$ just as black consciousness will be seen to carry the seed of a more humane society, compassionate and benevolent. We would then, and only then, concur with what Biko (1978:108) said: 'We have set out on a quest for true humanity, and somewhere on the distant horizon we can see the glittering prize'.

\section{Acknowledgements Competing interests}

The author declares that he has no financial or personal relationships which may have inappropriately influenced him in writing this article.

\section{References}

Allen, J., 2006, Rabble-rouser for peace: The authorised biography of Desmond Tutu, Free Press, London.

Bakhtin, M.M., 1981, The dialogic imagination, University of Texas Press, Austin.

Berggren, E., 2016, Catholicity challenging ethnicity. An ecclesiological study of congregations and churches in post-apartheid South Africa, Uppsala University Press, Uppsala.

Biko, S., 1978, I write what I like, The Bowerdean Press, London.

Burnley, L., 2008, The cost of unity. African-American Agency and education in the Christian Church, 1865-1914, Mercer University Press, Macon, GA.

Cone, J., 1969, Black theology and black power, Orbis Books, Maryknoll, NY.

Cone, J., 1972, A black theology of liberation, Orbis Books, Maryknoll, NY.

Cone, J., 1979, 'A black American perspective on the future of African theology', in G.S. Wilmore \& J.H. Cone (eds.), Black theology: A documentary history, 1966-1979, pp. 492-502, Orbis Books, Mariknoll, NY.

Du Bois, W.E.B., 1961 [1903], The souls of black folk, Fawcett, Greenwich, CT.

Eze, E., 2011, 'Double consciousness and the democratic ideal', in J.T. Levy \& I.M. Young (eds.), Colonialism and its legacies, pp. 219-242, Lexington Books, Lanham, MD.

Fanon, F., 1952, Black skin, white masks, transl. R. Philcox, Grove Press, New York.

Gilroy, P., 2003 [1993], The black Atlantic. Modernity and double consciousness, Harvard University Press, Cambridge, MA.

Gutierrez, G., 1978, 'Two theological perspectives: Liberation theology and progressivist theology', in S. Torres \& V. Fabella (eds.), The emergent Gospel. Theology from the developing world, pp. 227-255, Geoffrey Chapman, London (Papers from the Ecumenical Dialogue of Third World Theologians, Dar es Salaam, August 5-12, 1976).

Khabela, G.M., 1991, 'A seamless garment: Tutu's understanding of the role of the church in South Africa', PhD thesis, Union Theological Seminary, New York.

Maluleke, T., 2015, 'Desmond Tutu's earliest notions and visions of church, humanity and society', The Ecumenical Review 67(4), 572-590.

Mbiti, J.S., 1979, 'An African views American black theology', in G.S. Wilmore \& J.H. Cone (eds.), Black theology: A documentary history, 1966-1979, pp. 477-482, Orbis Books, Mariknoll, NY.

Selasi, T., 2014 [2013], Ghana must go, Penguin Books, London.

Sparks, A. \& Tutu, M., 2011, Tutu: The authorized portrait, Macmillan, Cape Town.

Tutu, D., 1979, 'Black theology/African theology - Soul mates or antagonists?', in G.S. Wilmore \& J.H. Cone (eds.), Black theology: A documentary history, 1966-1979, pp. 483-491, Orbis Books, Mariknoll, NY.

Tutu, D., 2015, In God's hands: The archbishop of Canterbury's lent book 2015, Bloomsbury, London.

Tutu, D. \& Tutu, M., 2014, The book of forgiving: The fourfold path for healing ourselves and our world, Harper Collins, London.

Vellem, V.S., 2015, 'Uprising faith praxis for the blackness of humanity', The Ecumenical Review 67(4), 651-663.

21.Catholicity as 'regarding the whole' was clearly demonstrated by the City Harvest Ministries of Apostolic Faith Mission, at Ntuzuma township south of Durban (see Berggren 2016:273). 